\title{
Economic Growth, Financial Depth and Lending Rate Nexus: A Case of Oil Dependant Economy
}

\author{
Najeeb Muhammad Nasir ${ }^{1}$, Nasir Ali ${ }^{1} \&$ Imran Khokhar $^{2}$ \\ ${ }^{1}$ Department of Finance, King Saud University, Riyadh, Saudi Arabia \\ ${ }^{2}$ Department of Economics, King Saud University, Riyadh, Saudi Arabia \\ Correspondence: Najeeb Muhammad Nasir, Department of Finance, King Saud University, Riyadh, Saudi Arabia. \\ E-mail: nnasir@ksu.edu.sa
}

Received: January 20, 2014

Accepted: February 18, 2014

Online Published: March 30, 2014

doi:10.5430/ijfr.v5n2p59

URL: http://dx.doi.org/10.5430/ijfr.v5n2p59

\begin{abstract}
This research empirically investigates the long and short run causal relationships between economic growth, financial depth and lending rate in the unique economic setup of Saudi Arabia where $92 \%$ of total GDP comes from oil exports. Study uses two proxies for financial depth namely liquid liability indicator and banks claim to the private sector to GDP ratio, while economic growth is measured by real GDP per capita. This study intends to get answers for such questions as, if financial depth effects or causes economic growth in an oil based economy, and does lending rate have any relationship with financial depth or economic growth. Using the Johansens co-integration, Granger causality and Vector Error Correction Model (VECM) the study finds a single co-integrated equation which establishes a long run relationship among the variables. Finding suggests that financial depth causes lending rate which is in contradiction with most of the available literature; the study tries to explain this type of causality under the present circumstances. Furthermore no short term significant relationship exists among the variables as reflected by the results of the Wald Test, that is due to the unique political and economic setup under consideration.
\end{abstract}

Keywords: co-integration, economic growth, financial depth, lending rate

\section{Introduction}

The Kingdom of Saudi Arabia is the world biggest economy based on oil production and exports where $92 \%$ of the total GDP is generated from this sole source. Efforts are underway to change the country's economic setup into a knowledge based economy where reliance on oil revenue is minimal in the next twenty years. The country is trying to enhance its financial development and productivity to accomplish this objective. There is emerging trend in the financial sector to produce multiple financial services adding to value of this sector so lending rate should also have predominant importance. The Saudi Arabian economy is observing high growth since 2010 as world economic recovery raised up Oil prices, and the government has increased the fiscal expenditure which augmented domestic demand and improved the growth in non-oil revenues. At the same time, the annual budget of the country recorded a surplus of SAR 87.7731 billion which is $4.4 \%$ of GDP in 2010 that was in deficit of SAR 86.6629 billion or $-5.4 \%$ of GDP in 2009. This increase continued and in 2012 the surplus was 374.093 or $14 \%$ of GDP. According to Saudi Arabian Monetary Agency (SAMA) the ratio of public debt to GDP dropped from $37.3 \%$ in 2005 to $9.9 \%$ in 2010 which continued to blur and in 2012 as it decreased to 3.7\% (SAMA, 2013).

Since the start of $20^{\text {th }}$ century there has been extensive research studies conducted on the topic of economic growth and financial development. All these studies portrayed the importance of financial development for the economic growth of the countries. Moreover recent studies conducted on the world economy suggested that the financial deepening can bring economic benefits. However the researchers have divided opinions on the nexus between financial depth and economic growth. Researchers such as Mckinnon (1973), shaw (1973), King and Levine (1993) support the view that Financial depth leads to Economic growth this view has its origin from Schumpeter (1912). Robinson (1952) argued that it is the Economic growth that leads to financial development; Patrick (1966) argued that the direction of causality changes from time to time. Researchers such as Wood (1992), Akinboade (1998, 2000), Luintel and khan (1999) and Odhiambo (2005) proposed that the relationship is two-way, that both cause each other.

As mentioned that there are extensive research studies on the topic but little is done on the unique environment of Saudi Arabia. Moreover most of the research studies conducted relying on the bivariate framework to see the causal 
relationship between them there may be a variable such as lending rate that effect both financial depth and economic growth. Although there is remote evidence from the research studies that lending rate has positive effects on economic growth but according to Odhiambo (2008) interest rate does affect financial depth and hence economic growth.

This research study attempts to find the relationship between economic growth, financial depth and lending rate where two proxies for financial depth is used and lending rate is used as third variable thereby creating a tri-variate model. The remaining paper is structured as: section 2 presents literature, section three is the methodology, section 4 is analysis and discussion and finally section 5 conclude the article.

\section{Literature Review}

The emerging body of empirical research on financial deepening and economic growth has used some econometric techniques and tools from cross-country regressions to macroeconomic investigations in order to establish the relationship and its direction (King and Levine, 1993). Some of the famous research studies in the past on these topics include work done by Schumpeter (1911), McKinnon (1973) and Shaw (1973), the recent approaches include extensive research by King and Levine (1993a) and Levine and Zarvos (1993) about exploring and explaining the relationship between financial development and economic growth in various regions through empirical methods. These researchers forwarded key arguments and suggestions in accordance with their findings on the topics. Most of them were in agreement that the surplus funds would be directed efficiently to the sectors with a shortfall to fuel the economy. They are convinced that financial intermediaries play an important role to create financial depth and trigger economic growth in the country. As mentioned by Greenwood and Jovanovich (1990) also offer evidence of increase in the income levels generates the savings and investment to strengthen the financial sector and economic growth through the role of financial intermediaries.

In one of the research the regression analysis confirmed the long term positive relationship between the level of financial depth and economic growth for developed countries with high per capita income but it was insignificant in long term for developing countries (Deidda and Fattouh, 2002). In another study Rousseau and Sylla (2001) observed many countries over the period 147 years and found proof of an important role of financial development in economic stability and growth. This supported previous study by Rousseau and Wachtel (1998) who established these relationships for industrial and non-industrial economies.

As mentioned before that the literature on the finance-growth nexus has used both the cross-sectional and the time series approach. Using a cross-sectional approach by taking the average of data for longer time periods and applying cross-sectional regressions to at explain the cross-country deviations in growth rates as taken applied by King and Levine (1993), Gelb (1989), Fry (1996) and others. But many researchers also criticize on their approach and technique. The lacking is also established by researches using this tool themselves by pointed out shortcomings of the approach in their own research.

Still the standard paper about the finance-growth literature is the King and Levine (1993) the study that covers the 29 years and focuses on 77 countries of the world. A development in that paper was that the authors used various proxies for financial development, mostly the financial depth measures relating to them with economic growth variables. Despite valuable contribution the researchers acknowledges the gap and lacking in research with reference to application of time series approach which is considered to generate more reliable results.

But the results obtained from Time series analyses by various research studies have not able to clarify the relationship between finance and growth to an extent. De Gregorio and Guidotti (1995) discussed the advantages and drawbacks of various financial depth proxies. Interestingly he found a negative relationship between financial depth and economic growth. The Recent studies have also tried to explain this relationship by using panel data analysis .As Beck and Levine (2004) looked at financial development through financial intermediaries and markets and found strong relationship in this regard.

The study found multiple possibilities after reviewing the existing literature regarding the causative relationship between financial depth and economic growth. One possible outcome was observed that financial development and economic growth is not causally related and there exist no short or long run association (Graff, 1999). Some others studies found some kind of causal relationship in this regard both for short and long term using empirical analyses and approaches. The work relating to determine this issue in developing countries includes studies such as King and Levine (1993), Odedokun (1996), Ahmed and Ansari (1998), Ghali (1999), Xu (2000), Jalilian and Kirkpatrick (2002), Suleiman and Abu-Qaun (2005), and Habibullah and Eng (2006). While the empirical researches which oppose the notion that that economic growth causes financial development comprised work done by Agbetsiafa 
(2003), Waqabaca (2004), Odhiambo (2007) and others mostly relying on results coming from less developed countries of sub Saharan Africa.

At the other hand lending rate changes and manipulations can be categorised as part of the broader financial plan. The governments in many countries specifically has used the deregulation of interest rates, the elimination of credit controls, free entry into the banking sector, central bank autonomy, privatization of financial institutions and liberalization of international finance activities like trade and capital flows specially after the emergence of world trade organization (WTO) and propagation of free trade.

It was a general belief until early 1970s that low interest rates would promote investment spending and economic growth in any type of economic setup. That was in agreement with the Keynesian approach and neo-classical theories of their age (Molho, 1986). The most important study in the previous literature which argues that lending rate leads to financial development and hence to economic growth is taken from the framework, analysis and evidence of McKinnon (1973) and Shaw (1973) in the early seventies. The suggestion of McKinnon and Shaw suppressed financial sector hinders the economic growth in multiple ways and is not a simple relationship under consideration.

A study conducted in middle eastern region also depict same results in which innovation, particularly with regard to Islamic financial products has been observed under the influence of Islamic laws and jurisprudence . the study has observed that banks in Saudi Arabia are the least efficient among GCC countries, followed by those in UAE and Qatar hindering the financial development and hence the economic growth in the region, while the financial sector depth id more prevalent in GCC countries of Oman and Bahrain.

On the empirical facade, few studies have been conducted in less developed countries to observe the relationship between lending rate and real GDP per capita or other variable of economic growth. That also have generated with varying results as early observed by Fry (1980) in his study of 7 Asian countries with uncertain and volatile relationship between the interest rate changes and economic growth. Another research by Lanyi and Saracoglu (1983) found a positive and significant relationship between interest rates and economic growth while the World Bank sponsored research project also found a positive relationship between real interest rates and economic growth in most of the developing countries in the world (World Bank, 1989). Roubin and Sala (1992) conclude that financial tyranny has a tendency to to lower economic growth while Gibson and Tsakalotos (1994) cast suspicions on these results. The authors claim that the results of Roubin and Sala (1992) could suffer from missing variable bias because each measure of financial distress is added individually and specifically in the study. In another work on 64 developing countries, Khatkhate (1988) found no difference in average real GDP growth between countries having volatile real interest rates patterns. Similarly, De Gregorio and Guidotti (1995) determined that interest rates are not a good indicator of financial depth and performance. Gupta $(1984,1986)$, however, finds conflicting results between interest rates and economic growth in two studies. On the one hand, Gupta's (1984) cross-section study of 25 Asian and Latin American countries finds an unfavourable effect of higher interest rates on the rate of economic growdi. On the other hand, Gupta (1984) found sign that higher real interest rates raised economic growth in India and Korea which was also true for his second work on that topic (Gupta, 1986).

\section{Methodology}

This study intends to examine the relationship among Economic growth, Financial Depth and Lending rate in the unique economic setup of Saudi Arabia by using the following model.

$$
E c o g=f(F D, L R)
$$

where Ecog $=$ Economic Growth (real GDP per Capita), FD = Financial Depth and LR=Lending rate. Basic Equation can be rewritten as

$$
E c o g=f(L L I, P R I V Y, L R)
$$

Where we have used LLI and PRIVY as proxies for Financial Depth

And LLI=ratio of Liquid liabilities to GDP and PRIVY= ratio of claims by Financial institutions to the private sector / GDP

$\mathrm{LR}=$ annual Lending rate of central bank (SAMA).

The economic nexus can be stated in the form of econometric equation as under

$$
E \operatorname{cog} t=\alpha_{o}+\alpha_{1} L L I_{t}+\alpha_{2} P_{R I V Y}+\alpha_{3} L R_{t}+\varepsilon_{t}
$$

The aim of this research is to inquire the long run and short run relationship between economic growth, financial depth and lending rate. Economic growth is measured by Real GDP per capita while we have taken two proxies for 
financial depth i.e. Liquid liability indicator(LLI) which is a ratio of liquid liabilities to GDP where liquid liabilities are currency held outside the banking system of the country plus demand deposits and interest bearing liabilities of banks and non-bank financial institutions. Second Indicator for financial depth is PRIVY which is a key measure preferred in the empirical literature, it is the ratio of claims by financial institutions on private sector to GDP. Lending rate(LR) is another variable considered for determining the co-integration in this study which is the annual interest rate determined by Saudi Arabian Monetary Agency(SAMA), the central bank of Saudi Arabia.

\section{ADF test of Unit root}

In order to determine the relationship unit root tests are important in detecting the stationary behaviour of a time series data. In most cases economic and financial time series data shows non-stationary behaviour, therefore it is imperative to apply unit root test in order to avoid spurious outcomes because non-stationary data nullify the normal statistical test due to time varying variance. If the data is non stationary after first difference it means that the data follows a random walk and according to the Gauss-Markov theorem the series will not have a finite variance. In this case the ordinary least squares (OLS) will not yield consistent bound estimates. This study used two tests of unit root on the time series data which are the Augmented Dickey-Fuller test (ADF) and the Phillips- Perron (PP) tests.

While the equation with trend and intercept is as under.

$$
\Delta \mathrm{X}_{\mathrm{t}=} \beta_{0}+\beta_{1 \mathrm{t}}+\beta_{2} \mathrm{x}_{\mathrm{t}-1}+\sum_{i=1}^{k-1} \beta i \Delta \mathrm{X}_{\mathrm{t}-1}+\varepsilon_{\mathrm{t}} \quad \mathrm{i}=1,2,3 \ldots \ldots, \mathrm{k}
$$

In the above equations $\Delta \mathrm{X}_{\mathrm{t}}$ is a macroeconomic variable in a time period $\mathrm{t}$ and $\gamma_{0}$ is a constant term while $\Delta \mathrm{X}_{\mathrm{t}}=\mathrm{X}_{\mathrm{t}}$ $\mathrm{X}_{\mathrm{t}-1}$ " $\mathrm{t}$ " is a trend variable and $\varepsilon_{\mathrm{t}}$ is white noise error term.

For the model the Null and Alternative hypothesis are given as under,

$\mathrm{H}_{0}: \beta_{2}=0$ Data is Non Stationary

$\mathrm{H}_{1}: \beta_{2}<0$ Data is Stationary

The $\mathrm{H}_{0}$ hypothesis has a unit root that mean that data is non stationary and $\mathrm{H}_{1}$ hypothesis do not contain a unit root so data is stationary. In order to determine the presence of unit root problem, t-statistics and p-values are computed and matched with critical values at levels and first difference. If the critical values are more than t-statistic at levels that mean that we cannot reject the null hypothesis and the data is non- stationary. While at first difference if the $\mathrm{t}$-statistics is greater than the critical values at first difference we reject $\mathrm{H}_{0}$ that mean data is stationary. In order to compare the values Critical values for this test are taken from MacKinnon (1999).

\section{Phillip Peron Test (PP TEST)}

Another test was developed by Phillip and Perrons (PP_(1988) for non-parametric test of unit root. This test has an edge over ADF test in a way that it adjusts the issues of serial correlation and heteroscedasticity. Further research has verified this advantage of PP test over ADF. One important advantage of this test over ADF test is that it does not considers lag length. The hypothesis for both $\mathrm{PP}$ and $\mathrm{ADF}$ are same, the equation for PP test is as under.

$\Delta \mathrm{Y}_{\mathrm{t}}=\psi \mathrm{Y}_{\mathrm{t}}-1+\beta+\varepsilon_{\mathrm{t}}$

Where $\Delta$ denotes the first difference operator.

\section{Test for Co-integration}

When the issue of unit root has been established now the co-integration test shall be applied. Co integration describes that, even though the variables under study are non-stationary individually but the linear relation between two or more may still be stationary. Granger (1981) theory of co integration extended by Engle and Granger (1987) examines the long run relation by co integrating short term and long term relationship. If co-integration exists that would mean that there is a long run linear relationship among variables. This study uses multivariate co-integration method by Johansen and Jueslius (1990). This method tests the long term relationship among the non-stationary variables and hence tells the number of co-integrating vectors among the variables under study.

Johansen test produces two types of statistical results the first one is Unrestricted Co-integration Rank Test (Trace) and the second is Unrestricted Co-integration Rank Test (Maximum Eigenvalue). Trace test with H0 that there is at most " $\mathrm{S}$ " co-integrated equations and $\mathrm{H}_{1}$ that there is " $\mathrm{S}$ " or more co-integrating vectors. The other is Max- Eigen statistics with $\mathrm{H}_{0}$ that there exist " $\mathrm{x}$ " co-integrating vectors against $\mathrm{H}_{1}$ hypothesis of $\mathrm{x}+1$ co-integrating vectors. Johansen co-integration is sensitive towards lag length selection so this study uses optimum lag length. Johansen's methodology takes its starting point in the vector auto regression (VAR) of order $p$ given by

$$
\Delta \mathbf{X}_{\mathrm{t}}=\beta_{1} \Delta \mathrm{X}_{\mathrm{t}-1}+\mathrm{P}+\beta_{\mathrm{t}-\mathrm{p}-1}+\beta_{\mathrm{p}} \Delta \mathrm{X}_{\mathrm{t}-\mathrm{p}}+\mu+\varepsilon_{t}
$$

Where $\mathrm{Xt}$ is an $\mathrm{nx} 1$ vector of variables that are integrated of order one usually represented 
I (1) and $\varepsilon \mathrm{t}$ is an $\mathrm{nx} 1$ vector of white noise with a mean of zero and a restricted variance.

The equations used for Trace statistic is shown as under

$$
\Phi \operatorname{trace}(\mathrm{s})=-\mathrm{P} \sum_{s+1}^{n} \ln (1-\Phi * \mathrm{i})
$$

For Maxeigen statistic equation is shown as

$$
\Phi_{\max }(\mathrm{s}, \mathrm{s}+1)=-\mathrm{P}_{\ln }\left(1-\Phi^{*} \mathrm{~s}+1\right)
$$

When Johansen test is applied in the trace statistics $P$ denotes sample size and $\Phi$ denotes characteristic root. The study has made decisions on the basis results of trace statistic and Maxeigen values obtained from applying Johansen co integration test using Eviews.

\section{Granger causality and vector error correction model (VECM)}

After finding co-integration from Johanson results the study applied granger causality test in order to determine the direction of causality. According to Granger (1988), if two variables are co integrated and is stationary at first difference that means of I (1) order, than either first cause second or second cause first. There can be unidirectional or bi directional causation between them.

If in the results the set of variables are all of the order of I (1), we should not estimate them using ordinary regression analysis as there may be one or more equilibrium relationships between them. If the study finds in Johansen co integration to have one or more co-integrating vectors then the appropriate estimation method is a VECM. This technique rectifies to both short term variations in variables and divergences from equilibrium.

The following is the general equation for the VECM:

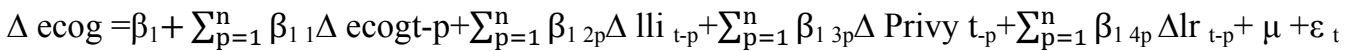

If the coefficient of test is a negative value and is significant at the same time than we can find the short run relationships by taking the coefficients of independent variables and applying a Wald test to ensure results. The study has used the Wald test is to determine the significance of explanatory variables in the statistical model.

Wald test is a statistical tools used for parametric analysis. Where an association among data variables can be stated as a statistical model in order to estimate parameters from a sample, this test can be applied to check the true value of the parameter based on the available sample estimate.

\section{Empirical Findings and Discussion}

In order to find the long term and short term relationship of economic growth with financial depth and lending rate the study has used three steps approach. At first step ADF and PP test- statistics has been employed to test whether the data is stationary or non-stationary. The results suggest that variables under study are non-stationary at levels while they are stationary at First difference that means the variables are of order I (1). In the second step, the study determined co-integration among variables by using Johansen co-integration approach. At third step Granger causality and VECM using Wald test were applied to determine the Causality and relationship.

\section{Unit root test}

Table 1 shows the results of unit root test indicating that at levels null hypothesis of no unit root cannot be rejected because the value of t-statistics is fewer than the critical value and p-value is insignificant in both Augmented Dickey-Fuller (ADF) and Philip-Peron's (PP) tests. This is not the case at first difference where the t-statistic is greater than the critical values and the p-values are significant so the null hypothesis rejected at their first difference.

\begin{tabular}{|c|c|c|c|c|c|c|c|c|}
\hline \multirow[t]{3}{*}{ VARIABLES } & \multicolumn{4}{|l|}{ At level } & \multicolumn{4}{|c|}{ At first deference } \\
\hline & \multicolumn{2}{|c|}{ With intercept } & \multicolumn{2}{|c|}{$\begin{array}{l}\text { With trend and } \\
\text { intercept }\end{array}$} & \multicolumn{2}{|c|}{ With intercept } & \multicolumn{2}{|c|}{$\begin{array}{l}\text { With trend and } \\
\text { intercept }\end{array}$} \\
\hline & t-stat & $\begin{array}{l}\text { C- } \\
\text { VALUE }\end{array}$ & t-stat & $\begin{array}{l}\text { C- } \\
\text { VALUE }\end{array}$ & t-stat & $\begin{array}{l}\text { C- } \\
\text { VALUE }\end{array}$ & t-stat & $\begin{array}{l}\text { C- } \\
\text { VALUE }\end{array}$ \\
\hline ECOG & -3.06332 & -3.60559 & -2.84262 & -4.19850 & -4.82864 & -3.60559 & -4.85955 & -4.20500 \\
\hline LLI & -1.599 & -3.6009 & -2.01571 & -4.19850 & -6.70650 & -3.60559 & -6.69867 & -4.20500 \\
\hline PRY & -0.61183 & -3.6009 & -3.85198 & -4.19850 & -6.32870 & -3.61045 & -6.25923 & -4.21186 \\
\hline LR & -0.18659 & -2.6250 & -5.2772 & -3.7700 & -5.3823 & -2.6256 & -5.4261 & -3.7700 \\
\hline
\end{tabular}
Consequently all the variables are stationary and integrated which means they are of the order I (1).

Table 1. ADF test 
Table 2. PP test

\begin{tabular}{lllllllll}
\hline VARIABLES & \multicolumn{1}{l}{ At level } & \multicolumn{3}{l}{ At first deference } \\
\cline { 2 - 10 } & \multicolumn{2}{l}{ With trend } & \multicolumn{3}{l}{$\begin{array}{l}\text { With trend and } \\
\text { intercept }\end{array}$} & \multicolumn{2}{l}{ With trend } & \multicolumn{2}{l}{$\begin{array}{l}\text { With trend and } \\
\text { intercept }\end{array}$} \\
\cline { 2 - 10 } & t-stat & $\begin{array}{l}\text { C- } \\
\text { VALUE }\end{array}$ & t-stat & $\begin{array}{l}\text { C- } \\
\text { VALUE }\end{array}$ & t-stat & $\begin{array}{l}\text { C- } \\
\text { VALUE }\end{array}$ & t-stat & $\begin{array}{l}\text { C- } \\
\text { VALUE }\end{array}$ \\
\hline ECOG & -2.857757 & -3.600987 & -2.862294 & -4.198503 & -4.815084 & -3.605593 & -4.914780 & -4.205004 \\
\hline LLI & -1.560992 & -3.600987 & -2.015710 & -4.198503 & -6.754142 & -3.605593 & -6.763217 & -4.205004 \\
\hline PRY & -0.124913 & -3.600987 & -3.638317 & -4.198503 & -11.39191 & -3.605593 & -11.38119 & -4.205004 \\
\hline LR & -0.015255 & -3.600987 & -2.169647 & --4.198503 & -6.284627 & -3.605593 & -5.987324 & -4.205004 \\
\hline
\end{tabular}

\section{Lag Order Selection Criteria}

The model is sensitive to lag length therefore the study utilized lag length criteria to get the optimal lag length. After getting the results as shown in the Table 3, the optimal lag length appropriate for this is lag order 2 as suggested by most of the selection criteria. The value is lowest at lag order 2 for Akaike information criterion (AIC) Final prediction (FPE), LR has been selected.

Table 3. VAR lag order selection criteria

\begin{tabular}{ccccccc}
\hline \hline Lag & LogL & LR & FPE & AIC & SC & HQ \\
\hline \hline 0 & -337.1111 & NA & 736.3854 & 17.95321 & 18.12559 & 18.01454 \\
\hline 1 & -186.2461 & 262.0286 & 0.612436 & 10.85506 & $11.71695^{*}$ & $11.16171^{*}$ \\
\hline 2 & -167.9503 & $27.92516^{*}$ & $0.559556^{*}$ & $10.73423^{*}$ & 12.28562 & 11.28620 \\
\hline 3 & -159.4553 & 11.17762 & 0.898235 & 11.12923 & 13.37013 & 11.92653 \\
\hline 4 & -145.3372 & 15.60421 & 1.160745 & 11.22828 & 14.15869 & 12.27090 \\
\hline
\end{tabular}

* indicates lag order selected by the criterion

LR: sequential modified LR test statistic (each test at 5\% level)

FPE: Final prediction error

AIC: Akaike information criterion

SC: Schwarz information criterion

HQ: Hannan-Quinn information criterion

\section{Johansen test of co-integration and Granger causality}

This study uses multivariate co-integration method by Johansen and Jueslius (1990). This method tests the long term relationship among the non-stationary variables and hence tells the number of co-integrating vectors among the variables under study.

Table 4. Johansen test of co-integration

\begin{tabular}{|c|c|c|c|c|c|c|c|c|}
\hline \multirow{2}{*}{$\begin{array}{l}\text { Hypothesized No of } \\
\text { CE(s) }\end{array}$} & \multicolumn{4}{|c|}{ Trace Statistics } & \multicolumn{4}{|c|}{ Max- Eiigen Statistics } \\
\hline & $\begin{array}{l}\text { Eigen } \\
\text { value }\end{array}$ & $\begin{array}{l}\text { Trace } \\
\text { statistics }\end{array}$ & $\begin{array}{l}\text { Critical } \\
\text { value } \\
5 \%\end{array}$ & prob & $\begin{array}{l}\text { Eigen } \\
\text { value }\end{array}$ & $\begin{array}{l}\text { Max-Eigen } \\
\text { statistics }\end{array}$ & $\begin{array}{l}\text { Critical } \\
\text { value } \\
5 \%\end{array}$ & Prob \\
\hline None $^{*}$ & 0.681078 & 74.75538 & 47.85613 & 0.0000 & 0.681078 & 45.71231 & 27.58434 & 0.0001 \\
\hline At most 1 & 0.388764 & 29.04306 & 29.79707 & 0.0609 & 0.388764 & 19.69087 & 21.13162 & 0.0785 \\
\hline At most 2 & 0.207844 & 9.352196 & 15.49471 & 0.3338 & 0.207844 & 9.319873 & 14.26460 & 0.2605 \\
\hline At most 3 & 0.000808 & 0.032323 & 3.841466 & 0.8573 & 0.000808 & 0.032323 & 3.841466 & 0.8573 \\
\hline
\end{tabular}


Trace test indicates 1 cointegrating eqn(s) at the 0.05 level

* denotes rejection of the hypothesis at the 0.05 level

**MacKinnon-Haug-Michelis (1999) p-values

Max-eigenvalue test indicates 1 cointegrating eqn(s) at the 0.05 level

Outcomes of co-integration test are stated in Table 4. This study used Economic growth as dependent variable while financial depth lending rate is considered as independent variables. Real GDP per Capita has been taken as a Substitute for real growth indicator. As there is probability of existence co-integrating relationships among variables. If the null hypothesis of no co-integration is rejected at none that means there is at least one co-integrated equation in the model. At $\mathrm{S}=0$ trace test statistic is 78.61 which is greater than critical value of 47.86 at $5 \%$ level of significance. The other estimator of Max- Eigen value is 52.91 which are also more than critical value of 27.58 at $5 \%$ level of significance. The p-values of both estimators also suggest the same results about significance. The results at none reject the null hypothesis of no co-integration at $\mathrm{S}=0$ hence there exists at least one co-integrated equation in the model. The outcome of the test confirms the existence of co-integrated relationship among the variables of Economic growth, financial depth and lending rate in the Kingdom of Saudi Arabia. That means the variables under study have long run relationship. Since there exists a long run relationship so it's suitable to determine the Granger causality.

The results of Granger causality indicate that PRIVY (financial institutions claim to private sector to GDP ratio) causes LR (lending rate) at $1 \%$ level of significance. It shows that there is a causal relationship between these two variables, but its unidirectional which runs from PRIVY to LR, which means financial deepening in the country effects the lending rate determination. Same is true with the other proxy of financial depth in which the LLI (ratio of liquid liabilities to GDP) causes LR that is also significant at 5\% level. These results show the impact and influence of financial institutions on financial decision making in the country. The other causations are insignificant and hence cannot be properly interpreted apart from economic growth which causes LLI at almost $10 \%$ level of significance.

Table 5. VECM results

\begin{tabular}{|c|c|c|c|c|}
\hline & Coefficient & Std. Error & t-Statistic & Prob. \\
\hline $\mathrm{C}(1)$ & -0.426959 & 0.101031 & -4.226013 & 0.0002 \\
\hline $\mathrm{C}(2)$ & -0.480798 & 0.260729 & -1.844053 & 0.0754 \\
\hline $\mathrm{C}(3)$ & -0.273235 & 0.241222 & -1.132710 & 0.2666 \\
\hline $\mathrm{C}(4)$ & -0.015288 & 0.033712 & -0.453491 & 0.6536 \\
\hline $\mathrm{C}(5)$ & -0.051586 & 0.035771 & -1.442108 & 0.1600 \\
\hline $\mathrm{C}(6)$ & -0.012603 & 0.010750 & -1.172308 & 0.2506 \\
\hline $\mathrm{C}(7)$ & -0.009645 & 0.011322 & -0.851893 & 0.4013 \\
\hline $\mathrm{C}(8)$ & -0.006611 & 0.015988 & -0.413520 & 0.6823 \\
\hline $\mathrm{C}(9)$ & -0.001860 & 0.016391 & -0.113471 & 0.9104 \\
\hline$C(10)$ & 0.120117 & 0.047599 & 2.523497 & 0.0174 \\
\hline $\begin{array}{l}\text { R-squared } \\
\text { Adjusted }\end{array}$ & \multicolumn{2}{|c|}{0.470522 Mean dependent var } & & 0.061125 \\
\hline R-squared & \multicolumn{2}{|c|}{0.306201 S.D. dependent var } & & 0.209936 \\
\hline S.E. of regression & \multicolumn{2}{|c|}{0.174866 Akaike info criterion } & & -0.433044 \\
\hline $\begin{array}{l}\text { Sum squared } \\
\text { resid }\end{array}$ & 0.886761 Schwarz criterion & Schwarz criterion & & -0.006490 \\
\hline Log likelihood & 18.44436 & Hannan-Quinn criter. & & -0.280000 \\
\hline F-statistic & 2.863436 & Durbin-Watson stat & & 1.703127 \\
\hline tatistic) & 0.015143 & & & \\
\hline
\end{tabular}

The Table 5 states the results of VECM. The first coefficient(Error correction term) is in negative with a value of -0.4269 and it is significant at with a $\mathrm{p}$ value of 0.0002 that means co integration exists and there is a long term relationship between Dependent and independent variables. The results shows long run causality runs from financial depth and lending rates to economic growth. The constant value C (10) is also significant representing the presence of intercept in the model. The value of $\mathrm{R}$ squared (coefficient of determination) states that variables included in model explain almost $47 \%$ of the response in the dependent variable economic growth. As economic growth is a general phenomenon and is affected by lot of variables so that is a good result to focus on some of the relatively 
important variable included to explain this relationship specially in case of Saudi Arabia which is dependent on oil. The F- statistics is also significant at $5 \%$ level with the value of 2.863 and corresponding probability of 0.01543 which shows significance of the model. We can comfortably reject the Null Hypothesis on the basis of the VECM results.

Table 6. Wald test

$\begin{array}{lcc}\text { F-statistic } & 1.480692 & 0.2131 \\ \text { Chi-square } & 10.36485 & 0.1688\end{array}$

The Wald test for short run causality can be applied if the results of VECM are significant. When the relationship is observed for short run causality it generates insignificant results as shown in the table. The F- Statistics is 1.480 with p-value of $21 \%$ and chi square is 10.364 with p-value of $16.88 \%$ showing insignificance of results. That means there is no short run causality between the variables under consideration.

Table 7. Residual diagnostics tests

\begin{tabular}{llclc}
\hline Diagnostic & $\begin{array}{l}\text { Langrange } \\
\text { statistics }\end{array}$ & multiplier & F-version & \\
\cline { 2 - 5 } & VALUE & P-VALUE & VALUE & P-value \\
\hline Serial correlation & 5.925637 & 0.0517 & 2.418674 & 0.1081 \\
\hline Heteroscedasticity & 18.49069 & 0.1016 & 1.953413 & 0.0744 \\
\hline Normality & 2.36936 & 0.305844 & N-A & N-A \\
\hline
\end{tabular}

In order test the validity of the model and to ascertain any discrepancies the study applied diagnostic tests for serial correlation, hetroscedasticity and normality. The results are stated in the Table 7. The results show that model is free from problem of serial correlation at 5\% level of significance. There are also no issues of hetroscedasticity and normality in the model. The results Shows the overall validity and reliability of the model.

\section{Conclusion}

This research study elaborates and examines the impact of lending rates and financial depth on economic growth in the oil based economy of Saudi Arabia. This research has been conducted to observe the relationship in the unique context and settings as $92 \%$ of the total GDP is generated from oil exports in the country. So it is interesting to see the effectiveness and relationships between Financial Depth, lending rates and economic growth in this unique setup. The other important factor to observe is the cultural and religious background and its implications with reference to financial activities as the country still follows the Islamic laws and regulations in which interest is strictly prohibited. Therefore lending rates does not effectively contribute towards GDP as can be observed by short run insignificant causality in the Wald test and same is true for Financial Depth measures. Although still there is a long term relationships between economic growth, financial depth and lending rate and the co-integration exists. Furthermore the Granger causality direction is from loans to private sector to lending rate and liquid liability indicators to lending which suggest that both the financial depth proxies cause lending rate which is opposite of the majority of research literature in this area where lending rate causes financial depth. It can be perceived from these results that in the economy like this interest rate changes does not guarantee financial development, certainly because of high dependency upon oil export. Unlike other countries where interest rate variations causes causes financial volatility. The mere results also depicts the strict control of the government on lending rate not allowing any free market forces to float in the country This study provides an insight about the economic growth, financial depth and lending rate in Saudi Arabia. The nutshell proposition of this research is that although the economic growth is driven by the oil exports, a currency pegged with U.S Dollar and avoidance from interest but still there exists relationship between financial depth lending rate and economic growth as shown in the results of VECM which states that there exists a long run relationship between dependent and independent variables. That mean the economic growth is dependent on the financial depth and lending rate in the long run in Saudi Arabian economy. 


\section{Acknowledgement}

The authors would like to thank the Deanship of Scientific Research at King Saud University represented by Research Centre at College of Business Administration for supporting this research financially.

\section{References}

Agbetsiafa, D.K. (2003). The Finance Growth Nexus: Evidence from sub-Saharan Africa. International Advances in Economic Research, 9(2).

Ahmed, Syed. M., \& Ansari, Mohammed I. (1998). Financial Sector Development and Economic Growth: The South-Asian Experience. Journal of Asian Economics, 9(3), 503-17.

Akinboade, O. A. (1998). Financial development and economic growth in Botswana: a test for causality. Savings and Development, 22, 331-348.

Akinboade, O.A. (2000). The relationship between financial deepening and economic growth in Tanzania. Journal of international development, 12, 939-950. http://dx.doi.org/10.1002/1099-1328 (200010)12:7<939::AID -JID $668>3.0 . \mathrm{CO} ; 2-\mathrm{I}$

Al-Yousif, Y.K. (2002). Financial Development and Economic Growth: Another Look at the Evidence from Developing Countries. Review of Financial Economics, 11(13), 1-150.

Ariss. R. T, Rezvanian. R., \& Mehdian. (2007). Cost Efficiency, Technological Progress and Productivity Growth of Banks in GCC Countries. International Journal of Business, 12(4), 471-487.

Boulila, G., \& Trabelsi, M. (2002). Financial Development and Long-run Growth: Granger Causalty in a Bivariate VAR Structure - Evidence from Tunisia (1962-1997). Working Paper, Faculte des Sciences Economiques et de Gestion de Tunis.

Chuah, H.L., \& Thai, V. (2004). Financial Development and Economic Growth: Evidence from Causality Tests for the GCC Countries. IMF Working Paper, W/04/XX.

De Gregorio, J., \& Guidotti, P.E. (1995). Financial Development and Economic Growth. World Development, 23(3), 433-448.

Deidda, L., \& Fattouh, B. (2002). Non linearity between finance and growth. Economic Letters, 74(3), 339-345.

Engle, Robert F., \& Granger, Clive W. J. (1987). Co-integration and Error Correction: Representation, Estimation, and Testing. Econometrica, Econometric Society, 55(2), 251-76, March. http://dx.doi.org/10.2307/1913236

Gelb, A. H. (1989). Financial Policies, Growth, and Efficiency. Working Papers, The World Bank; Country Economics Department, Policy Research and External Affairs. New York: Routledge, pp.138-58.

Ghali, K.H. (1999). Financial Development and Economic Growth: The Tunisian Experience. Review of Development Economics, 3(3), 10-322.

Gibson, H., \& Tsakalotos, E. (1994). The Scope and Limits of Financial Liberalisation in Developing Countries: A Critical Survey. The Journal of Development Studies, 30(3), 578-628

Graff, Michael. (1999). Financial Development and Economic Growth- A new Empirical Analysis. Dresden discussion paper series in Economics, Nr. 5/99 (Technische Universität Dresden). Retrieved from http:/hdl.handle.net/10419/48112

Granger, C. W. J. (1987). Implications of Aggregation with Common Factors. Econometric Theory, Cambridge University Press, 3(02), 208-222.

Granger, Clive W.J. (1988). Extracting Information from Mega-Panels and High-Frequency Data, University of California at San Diego. Economics Working Paper Series, Department of Economics, UC San Diego.

Gupta, K.L. (1984). Finance and Economic Growth in Developing Countries. Croom Helm Ltd.

Habibullah, M.S., \& Eng, Y. (2006). Does Financial Development Cause Economic Growth? A Panel Data Dynamic Analysis for the Asian Developing Countries. Journal of the Asia Pacific Economy, 11(4), 377-393. http://dx.doi.org/10.1080/13547860600923585

Johansen, S., \& Juselius, K. (1990). Maximum Likelihood Estimation and Inference on Cointegration - with Applications to the Demand for Money. Oxford Bulletin of Economics and Statistics, 52, $169-210$. http://dx.doi.org/10.1111/j.1468-0084.1990.mp 52002003.x 
Khatkhate, Deena. (1988). Assessing the Impact of Interest Rates in Less Developed Countries. World Development, 16(5), 577-588

King, R.G., \& Levine, R. (1993a). Finance and Growth: Schumpeter Might Be Wright. Quarterly Journal of Economics, 108, 713-37. http://dx.doi.org/10.2307/2118406

Lanyi, A., \& Saracoglu, R. (1983). Interest Rate Policies in Developing Countries. IMF Occasional Paper 22.

Levine R., \& Zervos S. (1998). Stock Markets, Banks, and Economic Growth. American Economic Review, 88(3), 537-558.

Luintel, K. B., \& Khan, M. (1999). A quantitative reassessment of the finance-growth nexus: evidence from a multivariate VAR. Journal of Development Economics, 60, 381-405.

McKinnon, R. I. (1973). Money and capital in economic development. Washington, DC. (USA): The Brookings Institution.

Molho, Lazarus. (1986). Interest Rate, Savings and Investment in Developing Countries: A Re-Examination of the McKinnon-Shaw Hypothesis. IMF Staff Papers, Vol. 33, pp. 90-111.

Odhiambo, N. M. (2005). Financial development and economic growth in Tanzania: a dynamic causality tests. African Finance Journal, 9, 1-17.

Odhiambo, N. M. (2007). Supply-leading versus Demand-following Hypothesis: Empirical Evidence from Three SSA Countries. African Development Review, 19, 257-280. http://dx.doi.org/10.1111/j.1467-8268.2007.00161.x

Odhiambo, N. M. (2008). Financial depth, savings and economic growth in Kenya: a dynamic causal linkage. Economic Modelling, 25, 704-713. http://dx.doi.org/10.1016/j.econmod.2007.10.009

Patrick, H.T. (1966). Financial Development and Economic Growth in Underdeveloped Countries. Economic Development and Cultural Change, 14(1), 174-189. http://dx.doi.org/10.1086/450153

Phillips, P.C.B., \& P. Perron. (1988). Testing for a Unit root in Time Series regression. Biometrika, 75, 335-346.

Robinson, J. (1962). Essays in the theory of economic growth. London (England): Macmillan.

Roubini, N., \& Sala-i-Martin, X. (1992). Financial repression and economic growth. Journal of Development Economics, 39, 5-30. http://dx.doi.org/10.1016/0304-3878(92)90055-E

Rousseau, P.L., \& Sylla, R. (2001). Financial systems, economic growth and globalization. NBER working paper, 8323. Retrieved from http://www.nber.org/papers/w8323.pdf

Rousseau, P.L., \& Wachtel, P. (2005). Economic growth and financial depth. Is the relationship extinct already? UNU-Wider discussion paper no. 2005/10. http://dx.doi.org/10.2139/ssrn.825744

SAMA. (2013). Forty Eighth Annual Report, SAMA. Retrieved 11-12-2013, from www.sama.gov.sa

Schumpeter, J. (1912). The theory of economic development (Reprinted 1961). New York (USA), Oxford University Press.

Shaw, E. S. (1973). Financial deepening in economic development. New York (USA) Oxford University Press.

Waqabaca, C. (2004). Financial Development and Economic Growth in Fiji, Working Paper 2004/03 (December), Economics Department, Reserve Bank of Fiji.

Wood, Anthony. (1993). Financial Development and Economic Growth in Barbados. Causal Evidence Savings and Development, 17(4), 379-390.

$\mathrm{Xu}$, Z. (2000). Financial Development, Investment and Economic Growth. Economic Inquiry, 38(2), 331 -344. http://dx.doi.org/10.1111/j.1465-7295.2000.tb00021 